\title{
LAWS RELATING TO THE INVESTMENT OF TRUST FUNDS, I930-1937
}

\author{
Gustav B. Margrap*
}

The period since rg2g has been one of unusual stress upon securities desirable for the investment of trust funds. Certain specifications set out in state legal lists, as, for example, dividend requirements for railroads, proved unduly restrictive in the light of prevailing business conditions. On the other hand, other types of securities were found to have too few criteria to assure reasonable safety. This was especially true of municipal obligations. These conditions, coupled with the synchronous increase in the volume of trust funds seeking investment, ${ }^{1}$ shrinkage of the mortgage market, and lowered returns on government obligations, combined to produce a need for the expansion of legal lists. The result has been the enactment in virtually every state of some legislation relating to trust fund investments.

Prior to I930 sixteen states expressly authorized investment in securities other than government and municipal obligations and mortgages. ${ }^{2}$ Since then the six states of Alabama, Florida, Indiana, Nebraska, Pennsylvania, and Tennessee have extended their lists beyond these three categories. In one state, Pennsylvania, a constitutional amendment was required to make this extension possible. ${ }^{2 x}$ Of those states which had comprehensive lists before I930, Connecticut, Delaware, Kentucky, Minnesota, New Hampshire, New Jersey, New York, Ohio, Oregon, Virginia, and Wisconsin have made significant changes. With the enactment by Congress of legislation to combat the depression during the years following 1930 virtually every state passed laws authorizing trustees to avail themselves of the investment opportunities offered by the newly-created federal agencies.

The purpose of this article is to collate the resulting mass of statutory material; not to evaluate it but to make possible its evaluation and the discernment of trends by those skilled in this field. The treatment follows a classification by type of security rather than by states. The securities will be discussed in the following order: ( $\mathrm{x}$ ) issues of the federal government and its agencies, (2) foreign, state, and municipal issues, (3) railroads, (4) public utilities, (5) other corporate issues, (6) mort-

- A.B., 1936, Cape Girardeau Missouri State Teachers College. Now a second year student in the Duke University School of Law. A member of the Editorial Board of the Duke Bar Association Iournal.

'See Riddle, Trust Investments: Their Extent and Some Related Economic Problems, supra at p. 34r.

${ }^{2}$ California, Connecticut, Delaware, Iowa, Illinois, Kentucky, Louisiana, Minnesota, New Hampshire, New Jersey, New York, Ohio, Oregon, Virginia, Washington, and Wisconsin.

$=\mathrm{Pa}$. Acts and Vetoes, Spec. Sess. 1933-34, no. 3, p. 338 . 
gages, and (7) miscellaneous. An eighth section sets forth provisions relating to trust investments generally. The legislation authorizing common trust funds, treated in another article in this symposium, has been omitted from this study.

Because of the very mass of material to be treated and the common defects in indexing and organizing this material in the session laws and statutory compilations, complete coverage and accuracy in the presentation of the new legislation cannot be assured. Moreover, changes in 1938 have not been included, with the exception of those in New York, where the information is based upon secondary sources. ${ }^{3}$ In view of the need for rigorous condensation in a treatment of this sort and the problems encountered in interpretation of statutes some inaccuracies of statement seem inevitable. However, since the purpose is to present the picture in the large, and not to furnish a guide for the selection of investments, it is hoped that such inaccuracies as may be encountered will not seriously impair the value of the study.

Throughout the article it has been necessary to endow terms with special meanings for purposes of condensation. Similarity of the criteria established by statutes of the various states has made possible this abbreviated means of expression. Thus, unless otherwise indicated, the word's "bonds" and "obligations" include bonds, notes, certificates of indebtedness, and other interest-bearing obligations. The term "no-default record" refers to the period of time immediately preceding the date of investment within which there has been no default in the payment of any part of the principal or interest on any funded obligation of the issuer. Since many states have provisions for a period of temporary default, the phrase "with an exception clause" indicates the period of temporary default permitted without impairment of the security's status. Where a requirement is stated in terms of a given number, the number represents, unless otherwise indicated, a minimum. Where the word "last" appears before a given number of years, the years denoted are those immediately preceding the date of investment. Terms applicable to particular types of securities will be explained in an introduction to each section.

Whenever possible the citations will be given to compilations of statutes. Since the compilations provide references to the session laws from which each compiled section is derived, those who wish to. refer to the laws of any one particular year may trace them without great inconvenience.

\section{Obligations of the United States and Its Agencies}

United States. Five states since 1929 have added new sections or altered existing ones which pertain to the investment of trust funds in the obligations of the government of the United States. Arkansas and Kentucky have expressly authorized investments in bonds of the national government; Indiana has extended the permission to bonds "which are the direct or indirect obligations" of the United States;"

\footnotetext{
${ }^{3}$ Other statutes enacted too late for inclusion in this study are: Georgia Laws Ist Spec. Sess. I937, p. 121; Kentucky Acts 1938, p. 227; New Jersey Laws 1938, cc. 52, 162, 196, 222.

'Ark. Acts 1931, C. 215; Kr. Stat. (Carroll, Baldwin's rev. 1936) 54706.

${ }^{5}$ INd. Stat. (Baldwin, Supp, 1937) $\$ 7908$.
} 
the Nebraska statute includes bonds and United States postal savings; ${ }^{\boldsymbol{B}}$ and Tennessee has added to the existing provision for investment in United States bonds, the authorization to invest in "notes and stock" of the national government." Except in Tennessee, which expressly permitted investments in United States obligations prior to I930, these authorizations are new.

Federal Home Loan Banks. Since I929 forty-three states have enacted legislation authorizing trustees or trust companies, or both, to invest trust funds in securities issued or insured by newly-created federal agencies. The first of such statutes appeared in 1933 , following the enactment the year before of the Federal Home Loan Bank Act. ${ }^{8}$ In that year nine states passed legislation expressly permitting investment in bonds issued under thàt act. Four states followed during the next year, four states in 1935 , and three in 1937.

In general, the statutes are of two types. Those of Delaware, Iowa, Kentucky, Michigan, Minnesota, Mississippi, New Mexico, New York, Ohio, and Tennessee ${ }^{8}$ name the bonds and other obligations of the Federal Home Loan Banks as legal investments. The statutes of California, Idaho, Illinois, Indiana, Maryland, Nevada, New Hampshire, Pennsylvania, South Carolina, and Texas ${ }^{10}$ add consolidated Home Loan Bank bonds and debentures, which are issued by the Federal Home Loan Bank Board and are the joint and several obligations of all the banks.

The laws of New Hampshire and New York provide for "investment" in the capital stock of home loan banks, whereas the Mississippi statute provides only that trustees may "exchange" existing obligations held by them for bonds of any home loan bank. The laws of Delaware and Maryland authorize trustees to "invest in" or "exchange for" such bonds, while the statutes in the remaining states mention only "investing."

Home Owners' Loan Corporation. Shortly after Congress had enacted the Home Owners' Loan Act of $1933^{11}$ the legislatures of several states passed laws relative to the investment in securities issued under that act. By the end of the year eleven states had such legislation. Six states passed similar statutes in 1934, four in I935, and one in 1937 .

A typical statute is that of Maryland, ${ }^{12}$ which provides that bonds issued by the HOLC shall be lawful investments for trust funds and that any fiduciary "that shall hold any mortgage or other lien on real or leasehold property, may at any time exchange, prior or subsequent to maturity, such mortgage or other lien and any

' Neb. CoMp. Stat. (Supp. 1935) \$27-601. TTenn. Laws I931, c. 100.

${ }^{8} 47$ STAT. 725 (I932), as amended, I2 U. S. C. A., C. II (I936).

${ }^{\circ}$ Del. Laws 1934, c. 37; Iowa Acts 1933, c. 165; Ky. Acts 1934, c. 13; Mrch. Comp. Laws (Mason, Supp. 1935) \$9805-II; Minn. Stat. (Mason, Supp. 1936) \$7714; Miss. Laws 1934, c. 213; N. M. Laws I933, c. 87; N. Y. Banking Law \$239; Ohio Laws I935, p. 250; Tenn. Acts Ist Spec. Sess. 1935, c. 36.

${ }_{10}$ Cal. Stat. 1937, c. 341; Idaho Laws 1937, c. 62; ILL. Rev. Stat. (Bar Ass'n ed., 1937) c. I48, \$32; Ind., supra note 5; MD. Code AxN. (Supp. 1935) art. 49A; Nev. Stat. 1935, c. 61; N. H. Laws I933, c. 27; 20 PA. Stat. Ann. (Purdon, Supp. 1937) §801; S. C. Acts 1935, no. 213, p. 287; Tex. Comp. Stat. (2d Supp. 1934) act 842 (a).

${ }_{41}^{11}$ STrT. 128 (1933), as amended, 12 U. S. C. A. c. 12 (1936).

Md. Laws Spec. Sess. 1933, c. 6r. 
rights in respect thereto for any of the bonds" of the HOLC "and may hold such bonds or any of them as authorized and lawful investments for any and all purposes, ..." Similar statutes have been passed in Delaware, New Jersey, New York, South Carolina, and Washington. ${ }^{18}$

The laws of the other states are more restrictive. In Illinois, Indiana, Kentucky, Michigan, Minnesota, Montana; Nevada, Ohio, Tennessee, Texas, and Wisconsin ${ }^{14}$ the express authorization extends only to "investment" in HOLC bonds and other obligations while the statutes in Arkansas, Mississippi, Oregon, Pennsylvania, and Wyoming ${ }^{15}$ mention only "exchanging."

Federal Savings and Loan System. The Federal Savings and Loan System was provided for by Section 5 of the Home Owners' Loan Act of $1933,{ }^{16}$ and amendatory acts. A year later the Federal Savings and Loan Insurance Corporation was created by Title IV of the National Housing Act. ${ }^{17}$ The Texas legislature in $1933^{18}$ was the first to authorize the investment of trust funds in the obligations of the federal savings and loan associations. In that year a law was passed which included as lawful investments "all bonds, debentures, notes, collateral trust certificates, and other such evidences of indebtedness which have been, or which may be issued by ... any federal savings and loan association." A New York statute passed in $1934^{10}$ permitted investments in shares of a federal association having an accumulated capital of $\$ 100,000$ or more. Six states followed with permissive legislation in 1935, and seven states in 1937 .

The statutes of California, Illinois, Indiana, Iowa, New York, Ohio, Pennsylvania, South Carolina, and Wyoming ${ }^{20}$ refer only to "shares" of the associations as legal investments. Arizona ${ }^{21}$ includes "investments certificates"; Connecticut" ${ }^{22}$ restricts the investment to an amount not exceeding $\$ 5,000$ in any one association; Idaho ${ }^{23}$ adds debentures issued by the FSLIC; and Texas ${ }^{24}$ specifies the several types of obligations in which investment is permitted. The Tennessee statute ${ }^{25}$ authorizes investment in "stock" of federal and state associations, and the Wisconsin act to $^{20}$ names "stock" of the federal associations and "bonds and evidences of indebtedness" of state building and loan finance corporations.

The savings and loan associations mentioned in the statutes of California, Connecticut, Ohio, New York, and Texas are only those chartered by the national gov-

\footnotetext{
${ }^{13}$ Del., supra note 9; N. J. Laws Spec. Sess. I933, c. I; N. Y. Real Prop. LAw c. 51; S. C. Acts 1934, no. 708, p. 1262; WASH. REv. Stat. (Remington, Supp. I937) \$55545-1, 5545-2.

"III., Nev., and Texas, all supra note ro; Ind., supra note 5; Ky., supra note 4; Mich., Minn., Ohio, and T'enn., all supra note 9; MoNr. Rev. CoDes (1935) \$5309.35; Wis. Laws 1935, c. 363 .

${ }^{15}$ Ark. Acts Spec. Sess. 1933, no. 10, p. 38; Miss., supra note 9; Ore. Code (Supp. 1935) \$22-1214; 20 PA. Stat. Ann. (Purdon, Supp. I937) \$802b; Wyo. Laws Spec. Sess. 1933, c. 57.

${ }^{15}$ Supra note $\mathrm{II}$.

${ }^{27}{ }_{48}$ STAT. 1246 (1934), 12 U. S. C. A. C. 13 (1936). $\quad{ }^{18}$ Supra note ro.

10 N. Y. Dec. Estate Lawi $5111 ;$ N. Y. Pers. Prop. Law \$21.

${ }^{20}$ Car. Gen. Laws (Deering, Supp. 1935) act 4241 \$1; Ill., Pa., and S. C., supra note I0; IND. Stat. (Baldwin, Supp. 1937) \$7722-1; Iowa Laws 1937, c. 220; Ohio, supra note 9; Wyo. Laws 1937, c. 91.

^ ARU. REv. CODE (Supp. 1936) \$6r 8b.

* Supra note 10.

supra note 9.

Conn. Gen. Stat. (Supp. r937) \$777d.

"Supra note ro.

*Wis. Laws 1935, c. 520.
} 
ernment, while the statutes of Arizona, Idaho, Illinois, Indiana, Iowa, Pennsylvania, South Carolina, Tennessee, Wisconsin, and Wyoming include both state and federal associations and similar institutions insured by the FSLIC.

Federal Housing Administration. The National Housing Act, passed in $1934{ }^{27}$ provided the stimulus for the largest group of state statutes authorizing the investment of trust funds in the obligations of a federal agency. Ohio in $1934^{28}$ was the first to include as legal investments notes or bonds secured by mortgages insured under the provisions of the National Housing Act, and notes, debentures, and other such obligations issued thereander. By the end of the following year more than half the states had enacted similar statutes. At the present time $3^{6}$ states have expressly conferred similar powers upon individual trustees or trust companies, or both.

Although the statutes in this group vary widely in their detailed provisions, they may be classified generally as to type. Those most extensive in scope are exemplified by the Wisconsin law, ${ }^{20}$ which provides as follows:

Credit unions, building and loan associations, investment associations, state banks, savings banks, trust company banks, land mortgage associations, insurance corporations, including life insurance companies, and fraternal benefit societies, executors, guardians, trustees, administrators, and other fiduciaries, except where it is contrary to will or other instrument of trust, the state of Wisconsin and its agencies and its municipalities, districts, and other subdivisions, and all institutions and agencies thereof, and all other persons, associations, and corporations, subject to the laws of this state are authorized:

(I) To make such loans and advances of credit and purchases of obligations representing loans and advances of credit as are insured by the federal housing administrator, and to obtain such insurance.

(2) To make such loans secured by real property or leasehold, as the federal housing administrator insures or makes a commitment to insure, and to obtain such insurance.

(3) To invest their funds, and moneys in their custody or possession (which are eligible for investment and which they are by law permitted or required to invest), in notes or bonds secured by mortgage or trust deed insured by the federal housing administrator, and in debentures issued by the federal housing administrator, and in securities issued by the national mortgage associations.

No law of this state requiring security upon which loans or investments may be made, or limiting the amount of loan to any stated proportion of the value of the security, or prescribing the nature, amount or form of such security or prescribing or limiting interest rates upon loans or investments, or prescribing or limiting the period for which loans or investments may be made, or prescribing or limiting periodical installment payments upon loans or securities, shall be deemed to apply to loans or investments made pursuant to this chapter.

It is significant that in this statute trustees and trust companies are authorized to make both loans and investments of a specific nature. Kentucky and Oklahoma ${ }^{30}$ have statutes almost identical to this. Idaho, New Jersey, North Carolina, and

"Supra note 17.

${ }^{20}$ Ohio Laws 1934, pt. II, p. $295 . \quad 20$ Wis. Laws 1937, c. 151.

${ }^{20}$ Ky. Stat. (Carroll, Baldwin's rev., 1936) \$94706-1, 4706-2; Okla. Laws 1937, c. 46. 
Oregon statutes, ${ }^{31}$ while different in form, differ in substance only in the omission of the authorization included in paragraph ( $\mathrm{r}$ ) of the Wisconsin act.

In a great majority of the states which have legislation of this nature there is no express authorization to trustees to make such loans as may be made in accordance with sections (I) and (2) of the Wisconsin statute. The statutes of Arkansas, California, Delaware, Florida, Illinois, Nebraska, North Dakota, New Hampshire, Ohio, South Carolina, Tennessee, Washington, West Virginia, and Wyoming ${ }^{32}$ are virtually identical to paragraph (3) of the Wisconsin law, both in form and in substance.

In Alabama and Virginia ${ }^{33}$ the express authorization to trustees includes only investments in mortgages insured by the Federal Housing Administrator. The Pennsylvania law ${ }^{34}$ includes, in addition to insured mortgages, debentures issued by him and guaranteed by the United States. Louisiana ${ }^{35}$ omits from the typical provisions the obligations of national mortgage associations; Montana ${ }^{36}$ includes as investment for trustees only FHA debentures but for the trust companies adds the obligations of the mortgage associations. Neither the debentures nor the obligations of the mortgage associations are expressly included in the New York law. ${ }^{87}$ The South Dakota statute ${ }^{38}$ includes "evidences of trust issued by a trustee, approved by the federal housing administrator, and secured by the deposit of entire mortgages insured by the Federal Housing Administration." The Texas statute ${ }^{30}$ differs from paragraph (3) of the Wisconsin law in that the authorization extends to investments in "mortgages, bonds, debentures, notes, collateral trust certificates, and other such evidences of indebtedness issued or that may hereafter be issued under the terms and provisions of the National Housing Act ... or by any lawful agency created thereunder."

The statutes of Kansas, Indiana, Michigan, Minnesota, Mississippi, Missouri, and New Mexico ${ }^{40}$ contain no authorization to individual trustees, only trust companies and other institutions being mentioned. There is, however, no other substantial deviation from the typical Wisconsin law.

In 1936 and again in $1937^{41}$ the Maryland legislature passed a statute similar to these, but both were vetoed.

A majority of the states which enacted legislation authorizing the investment of trust funds in the securities insured or issued under the NHA passed such statutes

\footnotetext{
aldaho Laws 1937, c. 26; N. J. Laws 1937, c. 90; N. C. Code (Michie, Supp. 1937) \$220(a) 2; Ore. Laws 1937, c. 54 .

"Ark. Acts 1937, no. 173, p. 646; CaL. Stat: 1937, c. 358; Del. Laws 1937, c. 133; Fla. Laws 1937, c. 17949; Ill., supra note ro; Neb. Laws 1937, c. 13; N. D. Laws 1937, c. 103; N. H. Laws 1935, c. 32; S. C. Acts 1937, no. 269, p. 406; Tenn. Acts 1937, c. 75; Wash. Rev. Stat. (Remington, Supp. 1937) \$5545-1; W. VA. CODE (1937) \$3202(2); Wyo. Laws 1937, c. 8.

${ }^{33}$ Ala. Acts 1935, no. 53, p. 124; VA. CODE (Michie, 1936) \$5431.

34 Supra note 10.

${ }^{25}$ LA. GeN. StATs. (Dart. Supp. 1937) \$610.14. ${ }^{38}$ Mont. Laws 1937, c. 24.

${ }^{37}$ N. Y. Dec. Estate Law \$III; N. Y. Pers. Prop. Law \$21.

${ }^{2}$ S. D. Laws 1937 , c. I6r.

${ }^{10}$ Kans. Laws 1937, c. 81; Ind., supra note 5; Mich. Laws 1937, no. 245, p. $3^{87}$; Minn. Laws 1937, c. 88; Miss. Laws 1936, c. 172; Mo. REv. STAT. (Supp. 1937) p. 1425; N. M. Laws 1937, c. 34

${ }^{4} \mathrm{Md}$. Laws Spec. Sess. 1936, c. 155; id. 1937, c. 168.
} 
first in 1935 and then, for the expressed purpose of clarification, amended them in 1937. 42 The later statutes, in general, simply eliminated the provisions which referred to the particular title of the NHA.

Farm Credit Agencies. Many states prior to $193^{\circ}$ had legislation which authorized trustees to invest in farm loan bonds issued by the federal land banks pursuant to the Federal Farm Loan Act of $1916 .^{43}$ Following the enactment by Congress after r930 of additional farm relief statutes, other states added legislation which authorized investment in securities issued by the federal agencies created for the purposes of farm relief. Recent statutes in Alabama, Colorado, Illinois, Nebraska, and South Carolina ${ }^{44}$ permit investments in bonds issued by the federal land banks. The new laws of Maryland and Texas ${ }^{45}$ specify obligations of the Federal Farm Loan Board. Iowa, Indiana, and Kentucky ${ }^{46}$ extend the authorization to all securities issued under the Federal Farm Loan Act and acts amendatory or supplementary.

Bonds and other obligations of the Federal Intermediate Credit Banks, created by the Agricultural Credits Act of $1923,{ }^{47}$ were made lawful investments for trust funds by New York in 1935, Kentucky in 1936, and Pennsylvania in 1937. ${ }^{48} \mathrm{~A}$ similar bill in Maryland, passed in 1937 , was vetoed. ${ }^{48^{*}}$

The five states of Illinois. Iowa, Kentucky, New York, and South Carolina ${ }^{49}$ have authorized investments in bonds and other obligations issued by the Federal Farm Mortgage Corporation, which was established under the authority of the Federal Farm Mortgage Corporation Act of $1934^{.50}$ The legislature of a sixth state, Maryland, ${ }^{51}$ sanctioned such investments, but the act died by veto.

Reconstruction Finance Corporation. Texas has a unique statute, passed in 1933,52 which permits investments in all bonds, debentures, notes, collateral trust certificates, and other such evidences of indebtedness which have been or may be issued by the Reconstruction Finance Corporation.

Agencies Unspecified. Other statutes have been passed by several of the states authorizing the investment of trust funds in securities without specification as to agencies. Seven states have recently enacted laws which expressly permit investment in bonds or other obligations which are guaranteed as to principal and interest by the federal government. Those states are Alabama, Delaware, Florida, Georgia, Idaho, Iowa, Nebraska, North Carolina, and Pennsylvania. ${ }^{53}$

\footnotetext{
a Because of the large number of 1937 statutes and their unimportance for the purpose of this study, citations to them have been omitted. 39 StAr. 360 (r916), 12 U. S. C. A. \$641 (1936).

"Ala. Acts 1935, no. 33, p. 65; Colo. CoMp. Laws (Supp. 1932) \$2767; Ill., supra note 10; Neb. Laws I937, c. 60; S. C. Acts I934, no. 879, p. I493. ${ }^{45} \mathrm{Md}$. and Texas, both supra note Io.

"Iowa Laws 1935, c. 119; Ind., supra note 5; Ky., supra note 4 .

${ }^{17} 42$ Stat. 1454 (1923), 12 U. S. C. A. $\$ 641$ (I936).

${ }^{4}$ N. Y. Banking Law $\$ 239$ (I0a); Ky., supra note 4; Pa., supra note 10.

use Md. Laws I937, c. I68.

${ }^{4}$ Ill., supra note 10; Iowa, supra note $46 ; \mathrm{Ky}$. , supra note 4 ; N. Y., supra note 48 ; S. C., supra note 44.

${ }^{50} 4^{8}$ STAT. 349 (1934), 12 U. S. C. A. \$1020h (1936).

s Supra note 482 .

Supra note 10.

Ala., supra note 44; DeL. Rev. Code (I935) \$440r; Fla., supra note 32; Ga. Laws 1935, no. 97, p. 483; Idaho Laws 1937, c. 62; Iowa Laws 1935, c. I19; Neb. Laws 1937, c. 60; N. C. Code (Michie, 1935) $5220(2)$; Pa., supra note 10.
} 
The Texas legislature in 1933 enacted a far-reaching statute ${ }^{54}$ which authorizes investments in evidences of indebtedness "which have been, or which may be issued by . . . any entity, corporation, or agency which has been or which may be created by or authorized by any act which has been enacted, or which may hereafter be enacted by Congress ...., which has for its purpose the relief of, or assistance to owners of mortgaged or encumbered homes, farms, and other real estate." Washington laws of 1933 and $1935^{55}$ permit trustees to invest in or exchange existing investments for bonds of any "corporation which is or hereafter may be created by the United States as a governmental agency or instrumentality." A 1935 statute of the Iowa legislature ${ }^{56}$ authorizes trust funds to be invested in "stock in any association or corporation created or which may be created by authority of the United States, when the purchase of said stock is necessary or required as an incident or condition of obtaining a loan from any association or corporation created or which may be created by authority of the United States as an instrumentality of the United States."

\section{Obligations of Foreign and State Governments and of Political Subdivisions of States}

More than a third of the states since 1929 have passed statutes dealing with the investment of trust funds in obligations of foreign and state governments and political subdivisions of states. Unless otherwise indicated, the special terms used in describing the changes will have the following meanings: "General obligations" are those for the payment of which the full faith and credit of the issuer are pledged; "net debt ratio" is the ratio of net debt to the most recently assessed valuation of the property in the district; "cities" refers to all incorporated places, including towns and villages; and "default" means default in the payment of any part of the principal or interest on any funded indebtedness of the obligor. The population criterion is determined by the most recent federal census.

Foreign Governments. Few states have amended their laws with regard to investments in foreign government bonds. A r937 Connecticut statute ${ }^{57}$ eliminated from the list of legal investments the bonds of Great Britain, Ireland, and France, leaving only those of the Dominion of Canada. 'Concerning the latter, the requirements were added that the bonds be payable in United States dollars within this country and that there be a no-default record of five years, with an exception clause of 90 days. Delaware and Wisconsin in 1935 enlarged their legal lists to include general obligation bonds of the Dominion of Canada, issued either by the government or any other debtor. ${ }^{58}$ Oregon has legalized investments in bonds of Great Britain and the Dominion of Canada or any province thereof, if payable in the United States and

\footnotetext{
Supra note to.

* Wash. Rev. Stat. (Remington, Supp. 1937) \$5545-2.

${ }^{*}$ Supra note $52 . \quad{ }^{\circ}$ Conn. Gen. Stat. (Supp. 1937) \$729d.

$\approx$ DeI. REv. CODE (1935) \$4401 (8); Wis. Laws 1935, c. 363.
} 
having a no-default record of five years. ${ }^{59}$ Tennessee's laws broadly permit investments in bonds and stock issued or guaranteed by any foreign government with which the United States has diplomatic relations, having a no-default record of 30 years, with an exception clause of 30 days; provided, that if such government has existed ten or more but less than 30 years, without default on its indebtedness, its bonds are legal investments. ${ }^{60}$

State Governments. A number of states have added to their legal lists certain obligations of state governments or have amended the clauses which concern such securities. Alabama in 1935 enacted for the first time for that state a legal list which includes bonds of all states. ${ }^{61}$ Arkansas now permits investments in bonds of that state. ${ }^{62}$ California has recently added to its state obligations the registered warrants of the state. ${ }^{63}$ Connecticut has removed the condition of admission to statehood prior to 1896 , and has increased the no-default record from ten to 20 years. ${ }^{64}$ It has removed also the provision for investment in certain bonds of states issued for funding or refunding defaulted obligations. ${ }^{65}$ Delaware has extended its list to include bonds of the District of Columbia and has added the requirement that the securities in this section be general obligations of states having a no-default record of five years, with an exception clause of six months. ${ }^{66}$ Florida's new legal list includes the bonds of any state (and Hawaii and Puerto Rico) which has a no-default record of ten years, with an exception clause of 90 days. ${ }^{67}$ Indiana has authorized investments in its own state bonds, whether direct or indirect obligations, ${ }^{\mathbf{6 8}}$ and in the bonds of other states having a no-default record of five years if the bonds are rated in one of the first three classifications established by one or more standard rating services specified by the Department of Financial Institutions. ${ }^{69}$ Kentucky in I932 authorized the investment in bonds and warrants of that state, including bridge revenue bonds issued by the Kentucky highway commission. ${ }^{70}$ The list adopted by Nebraska in I93 I includes bonds which are the general obligations of any state. ${ }^{71}$ In the same year Ohio added bonds of any state which has never defaulted. ${ }^{72}$ Oregon has added the requirement that the bonds, both of that state or any other state, must be the general obligations of the state, ${ }^{73}$ and Pennsylvania has inserted the same condition for its own bonds. ${ }^{74}$ In 193 I Tennessee added to the permitted investment in bonds of that state, the bonds and stock of any state or territory of the United States. ${ }^{\mathbf{7 5}}$ The Virginia law, which permitted investment in bonds of any state, has been extended to include stocks of any state, and the restriction adopted that the state must

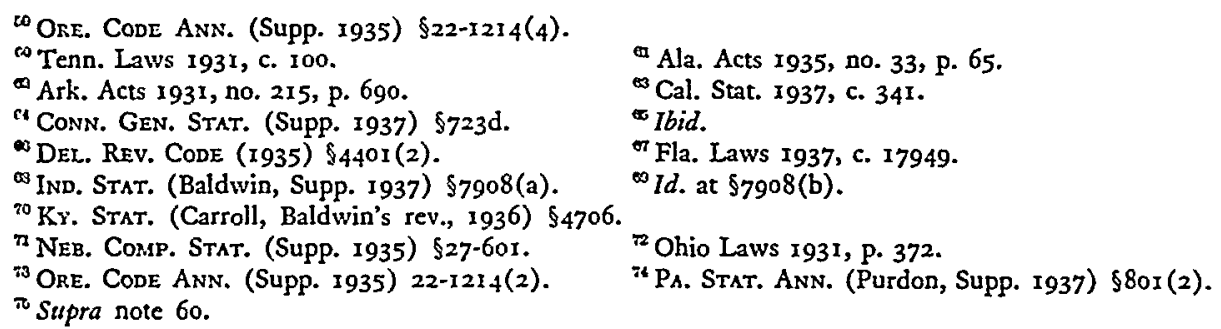


never have defaulted for more than 90 days. ${ }^{76}$ Wisconsin in 1935 removed the prohibition against investment in Nevada and Wyoming bonds and added a no-default record of ten years, with an exception clause of 30 days. ${ }^{77}$

Political Subdivisions of States. Eighteen states since I 29 have added to their legal lists certain obligations of political subdivisions of states or have amended their laws concerning such obligations. The general tendency has been to add a minimum population requirement where there was none before and to require some no-default record.

Alabama last year amended its list to include general obligation bonds of any county in the state having a no-default record of five years and also general obligations, including interest-bearing warrants, of any board of education of any county or municipality of the state, secured by pledge of the three mill school tax. ${ }^{78}$ Arkansas has authorized investments in bonds issued by any county of the state or by municipal improvement districts created by cities in Arkansas. ${ }^{9}$ California in 1937 added bonds issued by any city or city and county of the state with a population of 25,000 or by any department or board of such city or city and county, which are payable solely out of revenues from a revenue-producing utility owned, controlled, or operated by such city or city and county, or by any department or board thereof.80 Colorado has extended the authorization to bonds or stock of any consolidated school district of the state..$^{81}$ Connecticut has removed the requirement that the state in which the city is located have been admitted to statehood prior to $18966^{82}$ and has added bonds issued by any metropolitan district, created by special act, if the act has been approved and ratified by the electors of the several towns in such district. ${ }^{83}$

In Delaware the conditions have been made more stringent. The bonds of counties and of school districts within the state must be their general obligations, ${ }^{84}$ and for counties outside the state there have been inserted the following requirements: 50,000 population; net debt ratio, 3\%; direct and local and net debt ratio, $12 \%$; and a no-default record of five years, with an exception clause of six months. ${ }^{85}$ For municipalities outside Delaware have been added a population requirement of 100,000 , net debt ratio of $10 \%$, and a no-default record of five years, with an exception clause of six months. ${ }^{86}$ The authorizations in Florida are new. ${ }^{87}$ Investments may be made in general obligation bonds of any county or city outside the state which has a population of 40,000 , a net debt ratio of $7 \%$, and a no-default record of 15 years, with an exception clause of 90 days. For the general obligation bonds of any county, city, school district, or road and/or bridge district within Florida the population requirement is 2,000 and the no-default record and exception clause are five years and six months, respectively. There is no net debt ratio requirement. In Indiana investments may be made in the bonds of any county or city in any state, territory,

${ }^{75}$ VA. CODE (Michie, 1936) 5543 I (3).

${ }^{78}$ Ala. Acts Spec. Sess. 1936-37, no. 86, p. 99.

${ }^{90}$ Cal. Stat. 1937, c. 34 r.

Conn. Gen. Stat. (Supp. 1935) \$1487c.

${ }^{8 s}$ DeL. REv. Code $(1935) \$ 4401(3,5)$.

${ }^{\otimes} \mathrm{Id}$. at $\$ 440 \mathrm{I}(7)$.

7Wis. Laws I935, c. 363 .

supra note 62.

${ }^{81}$ Cozo. Comp. Laws (Supp. 1932) $\$ 2767$.

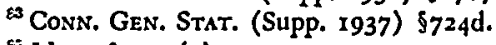

EId. at $\$ 4401(4)$.

bi Fla. Laws 1937, c. 17949. 
or insular possession of the United States having a population of 30,000 and a nodefault period of five years. ${ }^{88}$ There is no population requirement for the county, township, city, or other taxing district or municipality of Indiana, in whose bonds trustees may invest, though there must be a no-default record of five years, with an exception clause of six months. ${ }^{89}$

In I93 Minnesota included as legal investment for trust funds the bonds of any city in the state with a population of 50,000, or of any board of any such city, without regard to any debt limits other than those applicable to the issuance of such bonds. ${ }^{90}$ Two years later the bonds of villages and school districts qualifying under the act were made legal investments also. ${ }^{91}$ Nebraska has authorized the investment in bonds of any city, with a population of 200,000 , located outside the state, which has a no-default record of five years, with an exception clause of 90 days. ${ }^{92}$ The authorization extends also to general obligation bonds of any legally constituted political subdivision within Nebraska which has a similar no-default record and exception clause. ${ }^{93}$ A North Carolina law of r931 made applicable to the bonds of any city and school district in the state, the provision authorizing investments in bonds of counties in North Carolina. ${ }^{94}$ Ohio has added to its law which extended to the bonds of any county, city, or school district of the state which has never defaulted, the permission to invest in the bonds of "any other subdivision" and limited the no-default record to ten years, with an exception clause of 120 days.95

In I93I the Oregon legislature imposed the restrictions that the bonds be the general obligations of the political subdivisions issuing them, and for subdivisions outside the state a population requirement of 25,000 , and within the state, 2,000.96 Pennsylvania has added the qualification that at the date of the investment the political subdivision shall not be in default. ${ }^{97}$ The new list adopted in Tennessee in $193 \mathrm{r}^{98}$ includes the bonds of any county or city in any state or territory, with a population of 45,000 and a no-default record of 25 years, with an exception clause of 30 days. The population requirement for counties within the state is 15,000 , and the no-default record is 20 years, with an exception clause of 90 days. Virginia in 1936 extended the authorization to invest in bonds of cities outside the state to investment in bonds and stocks of any cities, counties, and districts in the United States. ${ }^{99}$ The population requirement was raised from 10,000 to 25,000, and the condition inserted that the subdivision have power to levy taxes on taxable real estate therein for the payment of such obligations without limitation of rate or amount. To the direct obligations of the issuing body were added obligations unconditionally guaranteed by the state. Wisconsin in I93 I raised the population requirement for cities outside the state from 25,000 to 30,000 , and for the obligations of cities both within and
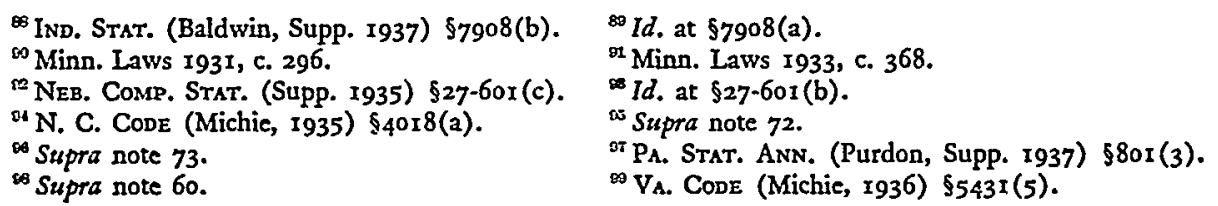
without the state inserted a no-default record of ten years, with an exception clause of 30 days. ${ }^{100}$

Several states since I929 have enacted laws authorizing investment in obligations of various state and local agencies. Perhaps the most important group of such statutes are those authorizing investments in the bonds of state housing authorities, which were passed in Arkansas, Colorado, Louisiana, Montana, North Carolina, Pennsylvania, and Tennessee. ${ }^{101}$ However, most of the statutes are restricted to specific issues, and, because of their limited and localized significance, they have not been included in this study.

\section{Railroad SEcurities}

Nine states since 1929 have made important changes in their laws relating to the investment of trust funds in railroad obligations. In three of these, Florida, Pennsylvania, and Tennessee, the express authorization to invest in railroad securities is new, and detailed specifications are set forth. New Hampshire and New York have simply added temporary provisions to meet the crisis caused by depressed business conditions. The remaining states, Connecticut, Delaware, Virginia, and Wisconsin, have made detailed alterations in the criteria imposed for such obligations. The changes in Connecticut have been the most drastic.

Throughout this section, unless otherwise indicated, "years" means fiscal years. "Net earnings" are the earnings available for fixed charges, ${ }^{102}$ and a "net earnings ratio" is the ratio of earnings available for fixed charges to fixed charges. "Total debt ratio" is the ratio existing between outstanding fully-paid capital stock and the funded debt of the corporation. ${ }^{102 x}$ "Shares of stock" refers to outstanding shares of capital stock. "Terminal property". includes terminals, depots, bridges, and tunnels; and "terminal bonds" are those secured by terminal property.

Because of the long and detailed, yet relatively standardized, specifications, the requirements for equipment trust certificates have not been set forth in this study.

Connecticut. The laws of Connecticut permit trustees to invest in securities legal for savings banks. ${ }^{103}$ Minor changes were made in the provisions relating to the obligations of railroads in I931 and $1933 .{ }^{104}$ In 1937 a general revision took place. ${ }^{105}$ The former law ${ }^{106}$ classified the accepted railroads according to place of incorporation and location of roads. Different. requirements were established for those railroads ( $\mathrm{I}$ ) incorporated in New England whose roads were wholly located there;

${ }^{200}$ Supra note 77.

${ }^{101}$ Ark. Acts 1937, no. 298, p. 1074; Colo. Laws 1935, c. 131; LA. Gen. Stat. (Dart, Supp. 1937) \$6z80.23; Mont. Rev. Codes (1935) \$5309.25; N. C. Code (Michic, 1935) \$6243(25); PA. StAt. AnN. (Purdon, Supp. 1937) §801 (18); Tenn. Acts Ist Spec. Sess. 1935, c. 20.

${ }^{100}$ The statutes of most states discussed herein define "fixed charges." Connecticut and Virginia adopted the meaning prescribed by the Interstate Commerce Commission for annual seports of railroads.

${ }_{10 c}$ This ratio for Pennsylvania and for Connecticut criteria for railroads is the ratio of the capital stock plus the total amount of obligations not containing an unconditional promise to pay interest thercon to the total amount of obligations containing such a promise.

${ }^{300}$ Conn. Gen. StAt. (1930) $\$ 4836$.

1ar CoNN. GEN. Stat. (Supp. 1931) \$54I(a); (Supp. 1933) \$1026b.

${ }^{20}$ Conk. Gen. Stat. (Supp. 1937) \$725d. ${ }^{100}$ Conn. Gen. Stat. (1930) \$3995. 
(2) incorporated in New England and having at least half their roads there; (3) incorporated in New England or in New York State and located wholly or in part there; and (4) incorporated elsewhere in the United States. The requirements were increasingly stringent in that order. The criteria employed were (a) mileage; (b) ratio of gross earnings to fixed charges; and (c) payment of annual cash dividends which, for all classes, must have equalled at least $4 \%$ per annum.

The I937 act divided the accepted railroads into two classes: "Qualifying Railroad Corporations" and (without apology to Hollywood) "Super-Qualifying Railroad Corporations," specifying requirements for the "eligible obligations" of each class. In the present law the geographical differentiation is dispensed with, and all railroads incorporated in the United States are treated alike. Street railways are excluded. The mileage requirement is now uniform and in the alternative with railway operating revenues, the former being 500 miles and the latter revenues of $\$ 10,000,000$ for the last fiscal year. The total debt ratio is limited to I to 3 ; the nodefault period is five years. In place of the dividend-paying condition there has been inserted the requirement of a net earnings ratio of $I \frac{3}{4}$ to $I$ for three of the last four years. For 1935 this ratio is fixed at 1 , and, for 1936 , at $1 \frac{1}{2}$ to $\mathrm{I}$. A "Super-Qualifying Railroad Corporation" is one which meets the above requirements, provided that in three of the last four years it has a net earnings ratio of 3 to I. A 2 to I ratio prior to 1937 will suffice.

"Eligible obligations" of a "qualifying" railroad are those issued, assumed or guaranteed by such railroad, and secured by (I) a mortgage which is a first lien on at least two-thirds of the total length of the lines mortgaged, including main line track between cities of 40,000 , and is subject to a mortgage inferior in lien, or, in the case of leased roads, protected by a rental sufficient to enable the lessor to pay dividents; or (2) a mortgage on property, all or a substantial part of which is terminal property; or (3) the irrevocable pledge of other "eligible obligations." Equipment trust obligations meeting certain specifications are included as eligible obligations.

"Eligible obligations" of a "super-qualifying" railroad are those meeting the above requirements and which are issued, assumed or guaranteed by a "superqualifying" railroad. Such obligations must be secured by either a first or refunding mortgage on $75 \%$ of the lines owned by the issuing railroad or by a mortgage prior in lien to an eligible refunding mortgage and covering property used by the "super-qualifying" railroad.

A significant provision in the 1937 law is that which states that nothing in this subsection will render illegal the investment in, or hereafter in, railroad obligations which were "legals" on January I, I937, so long as the obligations continue to comply with the laws in force at the time they were declared legal investments. Once such an obligation fails to comply with those laws it loses its status as "legal" until it complies with the 1937 act.

Delaware. Delaware laws, which, before 1930, permitted investments in mortgage bonds and in collateral trust bonds secured by guaranteed underlying stocks, 
where there was a no-default record of ten years, with an exception clause of ninety days, ${ }^{107}$ were amended first in $193^{108}$ and again in $1935^{100^{\circ}}$ The latter act authorizes investments in bonds secured by mortgages upon at least a part of the railroad property where the corporation has an average net earnings ratio of $x \frac{1}{2}$ to $x$ for the last five years, provided that, if the net earnings ratio in 1934 and r935 equalled $r$, an average ratio of I.2 to I for the five years would suffice. Added also was the authorization to invest in mortgage bonds assumed or guaranteed by an accepted railroad, if, as to such bonds, there is a no-default period of five years. The permission to invest in equipment trust obligations was qualified by new requirements. ${ }^{110}$

Florida. The provisions for investment in railroad obligations are part of the legdl list adopted in r93 and amended in 1937.111 Trust funds may be invested in mortgage bonds on railroad or terminal property assumed or guaranteed by a qualified railroad company. A "qualified railroad company" is one (a) incorporated in the United States; (b) owning and operating 500 miles of track within the United States; (c) having operating revenues during the last year from all its own or subsidiary lines of $\$ 10,000,000$; (d) having a no-default record of five years; and (e) having in four of the last five years a net earnings ratio of $x$, and in the last year a ratio of $\mathrm{I} 1 / 4$ to $\mathrm{x}$. The act defines net earnings and fixed charges.

New Hampshire. Temporary provisions were enacted in I933, I935, and $1937^{\mathbf{1 1 2}}$ to enable trustees to invest in obligations of certain railroads unable to meet the requirements set forth in the legal list. The New Hampshire laws ${ }^{113}$ provide that in each of the last three years the railroad must have had a net income of $\$ 10,000,000$ and at least $x 1 / 2$ times the annual interest on the obligations in question and all other obligations of equal or prior lien; or (b) a net income of $\$ 2,000,000$ and not less than $x 3 / 4$ times such interest. The emergency legislation of 1937 provides that until May 15, 1939, savings banks (whose authorized investments are legal for trustees) may, only upon the written approval of the commissioner, reinvest the proceeds of sale of railroad securities in mortgage bonds of roads having for the last three years an annual net income of $\$ 2,000,000$, a net earnings ratio of $r$, and not having defaulted during that time. The bonds must be secured by (a) first mortgage on property owned or operated by the railroad; or (b) a refunding mortgage covering $75 \%$ of the roads owned in fee as of its date and providing for the retirement of all outstanding mortgage debts prior in lien thereto.

The temporary provisions of the 1937 law provide also that mortgage bonds and senior obligations of railroads and terminals become legal investments upon certification by a Board of Investments ${ }^{113^{2}}$ created by the act and by the bank commissioner. No securities are to be certified except those of railroads incorporated before 1920

${ }^{107}$ Dex. Rev. CODE (1915) $\$ 3875$.

${ }^{100} \mathrm{DeL}$. Rev. Code (1935) $\$ 440 \mathrm{r}(\mathrm{ro})$.

${ }^{100}$ Del. Laws r93I, c. 259.

111 Fla. Laws 1931, C. 15064; Laws 1937, c. 17949.

${ }^{10}$ N. H. Laws 1933, c. 67; Laws 1935, cc. 32, II9; Laws 1937, c. 103.

113 N. H. Laws I929, c. 122.

Iuse The Board is to consist of five members appointed by the governor with the advice and consent of the council. 
and rated $\mathrm{A}, \mathrm{AA}, \mathrm{AAA}$ or equivalent by at least two recognized investment services approved by the commissioner. The Board, with the approval of the commissioner, may at any time remove a certified security.

New York. To meet exigencies created by the depression, New York in each year from $193^{2}$ to $1937,{ }^{114}$ inclusive, enacted "moratory" legislation to allow investment of trust funds in obligations of railroads no longer able to comply with the legal list requirements. The 1937 statute provided that, whenever in the section concerning railroad obligations a number of fiscal years is mentioned, each of the years beginning in I93 through 1936 should be excluded from the count if their inclusion would render the security ineligible. The statute provided also that railroad securities eligible for investment in I93 or which became eligible before April I, I938, would continue so until the latter date in the absence of default. This "moratory" legislation has not been re-enacted in 1938 , but a statute has been passed which allows trustees to continue to hold railroad obligations acquired prior to April, 1938 if such securities were eligible for investment when they were purchased.114*

Pennsylvania. Railroad obligations (other than those of street railways) were first authorized in $1935,{ }^{115}$ the statute being changed in some particulars in $1937 .{ }^{116} \mathrm{~A}$ "qualified railroad corporation" is one incorporated in the United States, owning and operating 500 miles of lines and having operating revenues, in the last year, of $\$ 15,000,000$ or more. Requisite are a total debt ratio of $\mathrm{I}$ to 2 , a no-default record of five years, and, during three of the last four years, a net earnings ratio to the fixed charges of the last year of $I$ for any years before $I 936$ and a ratio of $I \frac{1}{2}$ to $I$ for years after 1935 .

Eligible obligations are those issued, assumed, or guaranteed by a qualified road, either directly or by the terms of a lease extending twenty years beyond maturity of the obligation, and equipment trust obligations of a qualified road. The bonds are to be secured by (a) a first lien mortgage on two-thirds of the total roads covered, including through lines between two cities of 40,000 , and, unless the railroad is one having a net earnings ratio of 3 . to $I$ in each of the last three years, the mortgage is to be subject to an inferior lien, or, in the case of leased roads, protected by a rental sufficient to enable the lessor to pay dividends; or (b) secured by mortgage on terminal property; or (c) secured by the irrevocable pledge of other eligible obligations equal in amount and interest to the bonds secured.

Tennessee. In I93r an almost entirely new legal list was adopted.117 Eligible railroad obligations are those issued, assumed, or guaranteed by the railroad either directly or by the terms of a lease made or assumed by it and equipment trust obligations. The road is required either to own and operate 500 miles of track or have operating revenues of $\$ 10,000,000$ in each of five of the last six years. The net earnings ratio is fixed at $\mathrm{I} 1 / 2$ to $\mathrm{I}$ for a period of five of the last six years if the railroad

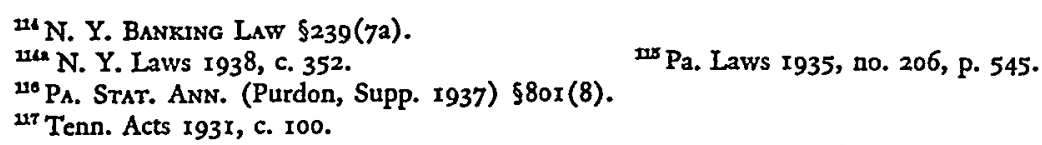


has paid cash dividends equalling $25 \%$ of its fixed charges; otherwise, nine of the last ten years. The railroad is required to have a six year no-default record. The bonds may be secured by direct mortgage on roads owned or operated by the obligor; on terminal property; or by the irrevocable pledge of other railroad obligations which are "legal." Other obligations are eligible if, in each of five of the last six years, the net earnings have been twice the sum of fixed charges (and full interest on such income mortgage bonds, if any), and the net income has been not less than \$ro,000 and the road has not been in default.

The investments in railroad obligations are limited to $25 \%$ of the assets of any trust, and in the obligations of any one road, $10 \%$ of such assets.

Virginia. The former law ${ }^{118}$ authorized trustees to invest in direct obligations of railroads, excluding street railways, whose lines were located at least partly in Virginia, provided the corporation had been in operation ten years without default on its indebtedness and had paid dividends out of income for the last two years to holders of all classes of its stock. In $1933^{119}$ there was added an authorization to invest in stocks and any other securities of a railroad whose lines had been leased by a railroad meeting these requirements at a rental sufficient to defray the lessor's operating and maintenance charges, and, in case of stock investments, to pay a fixed dividend upon the issue. The lease is to extend at least twenty years beyond the maturity date of the obligation or, if there is none, $5^{\circ}$ years beyond the date of investment.

In I93 $^{6}$ the qualifications for accepted railroad obligations were altered.120 Investments may now be made in obligations, including equipment trust obligations, issued, assumed or guaranteed by a railroad incorporated in the United States which meets the following requirements: (a) gross operating revenue of $\$ 10,000,000$ for each of the last five years; (b) average net earnings ratio averaging 2 to $I$ the last seven years and equalling $I \frac{1}{2}$ to $x$ the last year; and (c) the average market value of all outstanding securities junior to its bonded debt is equal to two-thirds of its total fixed charges for the preceding year capitalized at $5 \%$. The average market value is to be computed by averaging the highest and lowest market quotations for the calendar year of the investment and, if the expired portion of that year is less than six months, the calendar year preceding.

The 1936 law permits also investments in preferred stock of railroads operating within the United States and meeting the following requirements:121 (a) Cumulative stock preferred as to dividends and capital; (b) gross operating revenues of $\$ 10,000$,000 in each of the last five years; (c) a net earnings ratio to fixed charges plus preferred stock dividend requirements averaging $2 \frac{1}{2}$ to $I$ the last seven years and equalling 2 to $x$ the last year; and (d) an average market value of all outstanding securities junior to the preferred stocks, which is equal to the sum of the par value of the total issue of preferred stock in question and of all other preferred issues equal

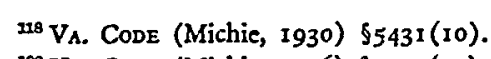

${ }^{200}$ VA. CODE (Michic, 1936) $\$ 5431(10)$.
110 Va. Laws I933, p. 79.
in Id. $\$ 543$ I (II). 
or senior in rank, and its total fixed charges for the preceding year capitalized at $5 \%$. The average market value is to be computed as indicated in the preceding paragraph.

Wisconsin. The Wisconsin law was amended in $1935 .{ }^{122}$ Before that time investments could be made in the mortgage bonds of any railroad within the United States owning and operating 500 miles of track and which had paid dividends upon its entire capital stock for the last ten years. ${ }^{123}$

In the new statute the mileage requirement is retained, but the dividend requirement is removed, and other criteria added. They are: (a) gross earnings of $\$ 10,000,-$ ooo during the last five years; (b) a no-default period of five years; (c) average net earnings ratio of $I \frac{1}{2}$ to $I$ for the last five years; and (d) a net earnings ratio of at least $I$ in each of those years.

\section{Public Utility Securities}

Connecticut, Delaware, Minnesota, New Hampshire, and Wisconsin have made major changes in their laws relating to public utility securities. New Jersey and New York have extended the scope of their provisions. Florida, Pennsylvania, Tennessee, and Virginia have added authorization to invest in such obligations, where no such express sanction existed before. The Virginia act contains detailed specifications for preferred stock of utilities in which investments may be made.

In this section the phrase "public utilities earnings requirement" refers to the minimum percentage of gross operating revenue which must be derived from the business of supplying the principal commodity or service of the utility in question. "Outside earnings" are those earnings derived from any one activity other than the supplying of the principal commodity or service, and "outside earnings restriction" is the maximum percentage of gross earnings which may be "outside earnings." "Franchise requirement" refers to the number of years which the franchise must extend beyond the maturity date of the obligation purchased. Other terms, including "net earnings," "net earnings ratio," "total debt ratio," and "years" are used with the same meaning as in the previous section.

Connecticut. The Connecticut law deals severally with the different types of public utilities. Amendments have been enacted in 1931, 1935, and 1937. The authorization to invest in obligations of companies supplying electricity and artificial gas has been extended to include those of utilities dealing in natural gas. ${ }^{124}$ The former restriction of $10 \%$ on outside earnings has been increased to $15 \%$, and the franchise requirement has been lowered from ten to five years. The r937 act ${ }^{\mathbf{1 2 5}}$ added to the provisions concerning investment in bonds of Connecticut gas and electric companies a permission to purchase debenture bonds of companies whose property is free from mortgage if the debentures are to be secured equally with any mortgage obligation subsequently issued.

The legislature in 1937 added a new provision relating to investments in telephone

\footnotetext{
123 Wis. Laws 1935, c. 363.

223 Conn. Gen. Stat. (Supp. 1937) \$73Id; (Supp. 1935) \$1494C; (Supp. 1931) \$545a.

${ }^{200}$ Conn. Gen. Stat. (Supp. 1937) \$727d.
} 
company obligations, eliminating the restriction to Connecticut companies, provided the net income for each of the last three years amounted to $\$ 50,000,000$ and to four times interest charges on outstanding debts, and the company's total debt ratio for the last year was at least 2 to $I_{.}{ }^{126}$ The provisions concerning Connecticut companies are unaffected by this section. In I93 these had been amended by repealing the provision which required the obligations to be secured by a first mortgage on at least $75 \%$ of the company's property and which limited the amount of the bonds issuable thereunder to $25 \%$ of such property. ${ }^{127}$ New criteria substituted were: (a) total debt ratio of $\mathrm{I}$; and (b) the payment from net earnings each year for the last four years of cash dividends of $4 \%$ on all capital stock.

The provisions concerning obligations of Connecticut water companies were amended in 193 I by the addition of the requirements that the company be the sole utility supplying water to communities of 15,000 in the state, that its franchise be unlimited in time, and that it have a total debt ratio of $\mathrm{I}^{128}$

Delaware. Before 193x trustees were allowed to invest in mortgage bonds of railroad, transportation, and public service corporations, with no other restrictions specified. ${ }^{129}$ A I93 amendment permits investments in mortgage bonds of public utilities which have had an average net earnings ratio of 2 to $x$ for the last five years. ${ }^{130}$ This was qualified in 1935 by an act which provided that if such period included 1934 or 1935 and if in those two years the corporations had a net earnings ratio of $x 1 / 2$ to $I$ a ratio averaging $x / 5$ to $I$ for the five years would suffice. ${ }^{131}$ The same act permits investment in mortgage bonds with a no-default record of five years and which have been assumed or guaranteed by a corporation qualifying above. ${ }^{132}$

Florida. The Florida provisions are parts of the legal list adopted in $193^{\mathrm{x}}$ and amended in $1937 .{ }^{133}$ Trustees are authorized to invest in bonds issued, assumed, or guaranteed by companies supplying artificial or natural gas, water, or electricity. The companies to qualify must be incorporated in the United States, operating under the jurisdiction of a public service regulatory body and, in the territory in which at least $75 \%$ of the gross revenues are obtained, under franchises granted by, or subject to, such body or extending at least five years beyond the maturity of the bonds. The corporation (and its predecessors) must have existed eight or more years, with a no-default record in the last eight years and a net earnings ratio averaging 2 to $I$ in the last five years and equaling 2 to $I$ in the last year. The public utilities earnings requirement is $75 \%$, with an outside earnings restriction of $15 \%$. The bonds must be part of an issue of $\$ 1,000,000$ or more, secured by a first or refunding mortgage on property owned and operated by the issuing or assuming company, or underlying mortgage bonds similarly secured. The aggregate principal amount of all first or

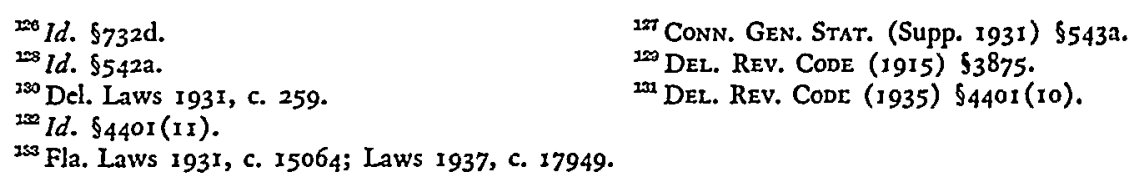


refunding mortgage bonds and all the underlying bonds is not to exceed $60 \%$ of the property owned and subject to these liens. Refunding mortgages must provide for the retirement by maturity of all bonds secured by prior liens.

The regulations for bonds issued, assumed, or guaranteed by telephone companies are the same as those for bonds of gas, -water, or electric utilities except that the minimum amount of the issue is set at $\$ 5,000,000$ instead of $\$ 1,000,000$ and the franchise and public utilities earnings requirements and the outside earnings restriction are omitted.

Minnesota. Minnesota amended its detailed requirements for public utilities securities in $1933^{134}$ Businesses supplying natural gas are now included. Provisions for gas, electric, and water companies remaining unchanged include incorporation, regulatory, franchise and public utilities earnings requirements, all of which are the same as those in Florida; and a total debt ratio of 2 to 3. The gross earnings requirement, formerly $\$ 1,000,000$ annually, with no limitation as to period, now calls for an average of that amount for the last five years. The net earnings ratio requirement of 2 to I for the period of the last five years has been altered to require such a ratio in each of those years. There has been added a new provision similar to the one in Florida, requiring existence for eight years, without default. The provisions for securing the bonds have been amended also. The former law required security in the form of first mortgage on all property of the issuing corporation, or a first and refunding mortgage containing provisions for retiring all prior liens. The security provisions of the $\mathrm{I} 933$ act are the same as those in Florida, with the additional requirement that mortgages junior to underlying mortgages must provide for the retirement or refunding of the latter, which, in turn, must either be closed or open only for the issuance of bonds to be pledged under the junior mortgage.

Before the 1933 amendment bonds issued, assumed, or guaranteed by telephone companies were subject to the same restrictions as bonds of gas, water, and electric utilities. ${ }^{135}$ The new statute deals with them separately, but differs only in removing the franchise and public utilities earnings requirements and the outside earnings restrictions and in providing that gross operating revenues must average $\$ 5,000,000$ annually for the last five years. The bonds must be part of an issue or subsequent series aggregating $\$ 5,000,000$, all protected by the same mortgage provisions. The security requirements differ in that there is no provision for security by underlying mortgage bonds. Not more than one-third of the property used as security may be stock or unsecured obligations of affiliated or other telephone companies.

New Hampshire. The permanent provisions concerning investments in obligations of public service companies were amended in 1931 and $1933^{136}$ and temporary provisions enacted in the latter year and in 1935 and $1937 .{ }^{137}$ For mortgage bonds issued, assumed, or guaranteed by a public service company or by its subsidiaries, if the parent company had reserved bonds for their refunding, either a net income of

${ }^{13}$ Minn. Stat. (Mason, Supp. I936) $\$ 7714$ (Io, II).

${ }^{150}$ MinN. Stat. (Mason, I927) \$7714(10). $\quad{ }^{180}$ N. H. Laws 193i, c. 96; Laws I933, c. 67.

${ }^{20}$ N. H. Laws 1933, c. 67; Laws 1935, cc. 32, I19; Laws 1937, c. 103. 
at least $\$ 500,000$ and a net earnings ratio of $13 / 4$ to $x$ or a net income of $\$ 250,000$ and a net earnings ratio of 2 to $I$ was required in each of the last three years. ${ }^{138}$ The I93I amendment removed the first alternative and lengthened the period to three of the last four years. For obligations other than mortgage bonds the requirements of net income of $\$ 500,000$ and a net earnings ratio of 2 to I were preserved, but the period was similarly lengthened. In 1933 investment in such issues was further restricted to companies whose total interest-bearing obligations do not exceed $65 \%$ of their assets and to issues protected by provisions prohibiting any increase in existing mortgage debts without equally securing or refunding or retiring the unsecured issues. The existing requirement, applicable to all issues, that the franchise extend at least to maturity was changed to three years beyond maturity. New provisions required the company to operate under a franchise covering at least $5 \mathrm{I} \%$ of its gross operating revenue or under an agreement with a public service commission equally protecting the bondholders' security.

Temporary provisions enacted in 1933 and re-enacted in 1935 and $1937^{130}$ allow savings banks, but only upon the written approval of the commissioner, to reinvest the proceeds of sale of public service company securities in their mortgage bonds eligible for investment on April 9, 1931, if in each of the last three years a net earnings ratio of $x 1 / 2$ to $I$ had been met. The same provision was made for mortgage bonds and senior obligations of public utilities certified by a Board of Investments as was made for such obligations of railroads, discussed above. ${ }^{140}$

New Jersey and New York. Both states, the former in $193 \mathrm{I}$ and the latter in $1932,{ }^{141}$ added to their laws concerning public utilities, companies engaged in the sale of artificial gas or a mixture of natural and artificial gas.

Pennsylvania. Express authorization to invest in obligations of natural and artificial gas, water, and electric companies was given first in 1935 and amended in 1937. 142 The qualifications for accepted companies are the same as those in Florida with the added requirement of a total debt ratio of 2 to 3 . The obligations are to be secured in the same manner as in Florida, except that, as in Minnesota, mortgages junior to underlying mortgages must provide for the retirement or refunding of the latter, which, in turn, must either be closed or open only for the issuance of bonds to be pledged under the junior mortgage. The mortgages in Pennsylvania may also be secured by the irrevocable pledge of other eligible obligations equal in amount and interest to the bonds secured.

The qualifications for accepted telephone companies and their bonds are the same as those for the other utilities, with the same exceptions as are made in Florida. ${ }^{143}$

Tennessee. The Tennessee statute which authorizes investments in companies supplying electricity and artificial gas, a part of the legal list enacted in $193 \mathrm{I},{ }^{144}$ is

\footnotetext{
${ }^{133}$ N. H. Laws I929, c. $122 . \quad{ }^{230}$ Supra note $137 . \quad{ }^{100}$ Sec p. 412 , supra.

14 N. J. Laws I931, c. 167; N. Y. Bankine Laws \$239(12).

${ }^{12}$ Pa. Laws 1935, no. 206, p. 545; PA. Stat. Ans. (Purdon, Supp. 1937) \$80I (9).

${ }^{123}$ Pa. Stat, ANN. (Purdon, Supp. 1937) $\S 801(10)$.

136 Tenn. Acts I931, c. roc.
} 
substantially the same as the corresponding Pennsylvania act, with the added requirement of annual average gross operating revenues of at least $\$ 1,000,000$ for the last five years and earnings in each year available for or paid in dividends of an amount equal to $4 \%$ upon a sum equivalent to two-thirds of the funded debt. The bonds are to be secured as in Pennsylvania except that there is no provision for security by way of pledge of other eligible obligations. The Tennessee statute imposes a further restriction limiting the amount of the assets of the trust which may be invested in such bonds to $25 \%$ and in any one such company to $10 \%$.

The criteria for telephone companies are the same as those imposed by the Pennsylvania act, with the added requirement of gross operating revenues for the last five years averaging $\$ 5,000,000$ annually, and earnings in each year available for or paid in dividends amounting to $4 \%$ upon all its outstanding capital stock. The bonds are to be secured as in Minnesota. The limitation on the amount of investment is the same as for other utilities.

Virginia. Virginia's legal list was amended in 1936 to include, among other changes, provisions for investment in obligations of electric and telephone companies, theretofore unauthorized. ${ }^{145}$ Companies operating in the United States and subject to a public service regulatory body qualify if they have had gross operating revenues of at least $\$ 10,000,000$ in each of the last five years; a net earnings ratio averaging $I^{3 / 4}$ to $I$ in each of the last seven years and equalling $I \frac{1}{2}$ to $I$ in the last year; and $a$ ratio of total par value of bonded debt (including subsidiaries) to gross operating revenues of not more than 4 to $x$. Electric companies within the act are those at least $80 \%$ of whose total revenue for the last year was derived from direct payments by customers for services rendered and which meet a $60 \%$ public utilities earnings requirement and, on traction operations, a 10\% outside earnings restriction. Telephone companies are subject to the $80 \%$ customer payment requirement only.

Virginia's legislature in 1936 sanctioned investments in the cumulative preferred stock of electric and telephone companies operating in the United States and subject to a public service regulatory body, if preferred as to dividends and capital. ${ }^{146}$ To qualify the company must have had gross operating revenues of $\$$ ro,000,000 in each of the last five years; net earnings ratio to fixed charges and dividend requirements for the preferred stock in question annually averaging 2 to $I$ for the last seven years and equalling $\mathrm{I} 3 / 4$ to $\mathrm{I}$ the last year; and a 4 to $\mathrm{I}$ ratio of the sum total of par value of the bonded debt and par value of the issue of preferred stock and other issues equal or senior in rank to gross operating revenues. The same requirements are imposed for revenue sources as for other obligations of the companies.

The 1936 amendment authorized also investment in obligations issued, assumed, or guaranteed by the American Telephone and Telegraph Company provided that the company and its subsidiaries had a net earnings ratio averaging $I 3 / 4$ to $I$ for the last seven years and equalling $I \frac{1}{2}$ to $I$ in the last year. ${ }^{147}$

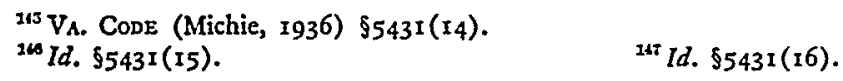


Wisconsin. Changes were made in the detailed provisions of the Wisconsin law in 1935.148 The former act ${ }^{149}$ relating to mortgage bonds of "any public utility" was changed so as to enumerate utilities supplying gas; electricity, water, and telephone service. Street railways were eliminated and the requirement that the company operate in cities of ro,000 removed. The former requirement of a ratio of gross earnings to interest charges on all mortgage debt equal or senior in rank to the bonds purchased of 6 to $\mathrm{I}$ for each of the last five years was removed and an annual gross earnings criterion of $\$ 1,000,000$ substituted. A net earnings ratio averaging 2 to $I$ for each of the last five years and equalling $I \frac{1}{2}$ to $I$ in the last year is now required in place of the former criteria of net earnings of $\$ 100,000$ and a net earnings ratio of $2^{1 / 2} 2$ to $I$ during each of the last five years. Other provisions of the former law have been retained in the 1935 amendment.

The legislature in 1935 added as "legal" obligations of constitutionally-sanctioned municipally-owned public utilities of Wisconsin, provided the net book value of the property pledged as security for such bonds has been established or approved by the public service commission, and the total issue of such bonds does not exceed 50\% thereof. ${ }^{150}$

\section{Securities of Corporations Other Than Railroads and Public Utultties}

Delaware, Illinois, New Hampshire, and Ohio since 1929 have altered their laws concerning investments in obligations of those corporations not included in the previous sections, and Indiana, Nebraska, Oregon, and Virginia have for the first time enacted legislation expressly authorizing such investments. Special terms used herein are given the same meaning as in previous sections.

Delaware. Prior to amendments in $193^{\mathrm{r}}$ the Delaware law, in addition to permitting investment in bonds of railroads and transportation and public service corporations, authorized investment in bonds of other corporations where secured by a first mortgage upon productive real estate free from prior liens. ${ }^{151}$ The $193 \mathrm{I}$ act reduced the security required by specifying merely that the bonds be secured by mortgage, but added a requirement of an average net earnings ratio of 3 to $\mathrm{r}$ for the last five years. ${ }^{152}$ An amendment in 1935 added mortgage bonds with a no-default record of five years and which have been assumed or guaranteed by a corporation qualifying above. ${ }^{153}$

Illinois. Illinois before $193^{\circ}$ permitted investments in first mortgage bonds of any corporation in the United States upon which there had been no default for five years..$^{153^{2}}$ In 1937 a statute was enacted authorizing trustees to invest in first mortgage bonds of corporations in the United States qualifying under the terms of the Federal Securities Act of 1933 and the Securities Law of Illinois, issued in whole or

\footnotetext{
14s Wis. Laws 1935, c. 363 .

${ }^{210}$ WIs. STAT. (1929) \$231.32.

201 Del. Rev. CODE (1915) \$3875.

${ }^{203}$ DEI. REV. CODE (I935) $\$ 4401$ (10).
}

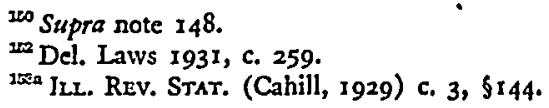


in part to refund any first mortgage bonds of such corporations eligible for investment at the time of refunding. ${ }^{154}$

Indiana. A legal list was enacted in Indiana in 1933 and amended in 1935 and I937..$^{105}$ The act as amended includes bonds and debentures of corporations with a no-default record of five years rated in one of the first three classifications established by at least one standard rating service specified by the Department of Financial Institutions and meeting the requirement of marketability prescribed by the department. ${ }^{156}$

Nebraska. The Nebraska legislature in 1935 authorized investment in obligations secured by first mortgage on real estate located at least partly in that state and issued by corporations doing business there and having a net earnings ratio averaging 2 to $I$ during the last five years and a no-default record of ten years. ${ }^{157}$ A provision was added in 1937 permitting a court, upon application by the trustee, to sanction investments in obligations of corporations organized elsewhere in the United States provided such obligations are rated by generally used publications of at least two statistical organizations in either of the two highest ratings of such organizations. ${ }^{158}$

New Hampshire. The provisions for investment in bonds of any New England manufacturing company which had earned during four of the last five years $4 \%$ dividends on its entire capital stock and which had a net debt not exceeding $50 \%$ of its unimpaired capital stock was restricted in $193 \mathrm{r}$ to companies engaged in manufacturing in New Hampshire and whose net income in four of the last five years at least doubled the interest on the bonds in question and others of equal or prior lien. ${ }^{159}$ The other requirements were removed. The criteria for companies in whose stock or certificates of interest trustees might invest were formerly the same as the criteria for bonds. ${ }^{100}$ The I93I act changed these to the requirement that the company have earned in four of the last five years net income available for $4 \%$ dividends on the entire outstanding issue of the stock purchased. This act added stock or certificates of interest in New Hampshire fire insurance companies with capital stock of $\$ 1,000,000$ and unimpaired surplus of $\$ 500,000$. The dividend requirement is the same as for manufacturing companies. The same act added to the provisions for investment in bonds secured by collateral dealt in on the Boston and New York exchanges, collateral dealt in on the New York Curb Exchange, but made no other change as to the requisites of the collateral.

Temporary provisions enacted in 1935 and extended in $1937,{ }^{161}$ permit investment in mortgage bonds and senior obligations of industrial companies, except holding companies, incorporated in the United States, if the obligations have been certified by a Board of Investments, with the approval of the bank commissioner. The provisions as to certification are the same as those for railroads and public utilities. ${ }^{162}$

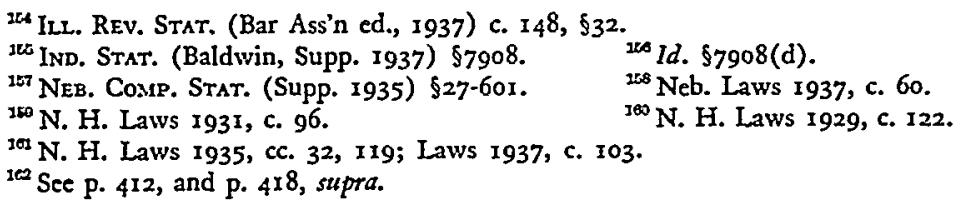


In 1937 permission was given to invest in those stocks of banks and trust companies which are legal for savings bank investment. ${ }^{163}$

Ohio. The former Ohio law included as "legal" bonds of corporations having a net earnings ratio of 2 to $I$ for the last four years and those of corporations whose bonds of the issue purchased and other prior incumbrances do not exceed $50 \%$ of the value of the property securing such bonds. ${ }^{104}$ This provision was removed in I937 and authorization substituted to invest in marketable obligations as prescribed by the Superintendent of Banks upon the approval of the Banking Advisory Board. ${ }^{105}$ The authorization to invest in stocks upon which dividends have been earned and paid for the last five years has also been removed and no provision comparable to the above substituted. ${ }^{186}$

Oregon. In I933 the Oregon legislature added to the legal list bonds listed on the New York Stock Exchange of any railroad, telegraph, telephone, electric, and water company having a no-default record of five years. ${ }^{107}$ For this provision there was substituted in 1935 an authorization to invest in bonds, other than foreign bonds, listed upon the New York, Boston, Chicago, or San Francisco exchanges or the New York Curb Exchange and on any other recognized exchange approved by the superintendent of banks, or bonds admitted to unlisted trading on the New York Curb Exchange, provided the obligor has had a no-default record of five years and the bonds are included in one of the four highest ratings of a rating service approved by the Superintendent of Banks. ${ }^{168}$

The provisions regarding investment by trustees for charitable and educational purposes were amended in $1937 . .^{189}$ The former law ${ }^{170}$ included stocks of private corporations listed on the New York Stock Exchange and in existence without default for at least ten years, having earned and paid dividends of $4 \%$ during the last five years. Not more than $20 \%$ of the funds held in trust might be invested in such stocks, and $2 \%$ in those of any one corporation. The amendment extended the authorization to stocks of any corporation listed on any stock exchange organized and existing in the United States. The period of existence was reduced to five years, the provision against default removed, and the limitation upon investment of funds in such stock increased to $35 \%$. The other criteria were retained.

Virginia. Virginia's amendment in $193^{6171}$ added bonds of industrial companies incorporated in the United States and having gross revenues of at least $\$ 10,000,000$ in each of the last five years, a net earnings ratio averaging 3 to $I$ in each of the last seven years and equalling $2 \frac{1}{2}$ to $I$ in the last. year, and a net working capital of at least twice the par value of its bonded debt. The average market value of all outstanding securities of the corporation junior to its bonded debt must be equal to the

\footnotetext{
${ }^{103}$ N. H. Laws 1937, c. 8.

${ }^{18 t}$ OHIO GEN. CODE ANN. (Page, 1926) \$710-111.

${ }^{100}$ Id. \$710-I 40 .

${ }^{2 e s}$ ORE. Code ANN. (Supp. 1935) \$22-1214(3).

${ }^{170}$ ORE. COde AN. (1930) \$32-803.
}

\footnotetext{
${ }^{10}$ OHo Gen. Code Ann. (Page, 1937) \$710-111

${ }^{107}$ Ore. Laws 2d Spec. Sess. 1933, c. 67.

19" Ore. Laws 1937, c. 29.

${ }^{171}$ VA. CODE (Michie, 1936) \$5431(17).
} 
total par value of the bonded debt at the time of investment. The average market value is to be computed in the same manner as for railroads.

The 1936 statute permits investments in the cumulative preferred stock of industrial companies incorporated in the United States if preferred as to both dividends and capital. ${ }^{172}$ The corporation must have had gross operating revenues of $\$ 10,000$,000 in each of the last five years; a net earnings ratio to fixed charges and dividend requirements for the preferred stock in question annually averaging 4 to I'for the last seven years and equalling 3 to $I$ in the last year; and a net working capital equal to the sum total of the par value of its bonded debt and that of the issue of the preferred stock purchased and other issues equal or senior in rank. The same total must be exceeded $2 \frac{1}{2}$ times by the aggregate of the lowest market prices of each of the outstanding securities of the corporation junior to the preferred stock. The lowest market price of any one security is to be the lowest single quotation of that security during the calendar year of the investment and the calendar year next preceding or, if the expired portion of the former year is less than six months, the two calendar years preceding.

\section{Mortgages and Ground Rents}

A third of the states during the past seven years have enacted legislation relating to mortgage provisions in legal lists. The laws concerning mortgage participations are collected and discussed in the latter part of this section. The term "debt limit" refers to the maximum percentage of the mortgaged property's value which the obligation in which the investment is made may be.

Alabama. The Alabama legislature in 1935 authorized investments in first mortgages on improved real estate in the United States. ${ }^{173}$ No other restrictions were imposed. An amendment in 1937 provided that a trustee is not to purchase from a trust under his control or from himself for any trust, any mortgages unless they were originally acquired by the trustee in good faith and with due diligence for trust investment.

Connecticut. Prior to I931 trustees were permitted to make investments with a debt limit of $50 \%$ on unincumbered real estate located in Connecticut and in certain counties in Rhode Island, Massachusetts, and New York. ${ }^{174}$ Mortgages are now limited to Connecticut real estate. ${ }^{175}$

Delaware. Trustees formerly were allowed to invest in bonds of natural persons and corporations secured by first mortgage on productive real estate free from prior liens. ${ }^{176}$ The legislature in $193 \mathrm{I}$ added a $60 \%$ debt limit, ${ }^{177}$ and in 1935 restricted the mortgages to those on land within the state, removing the requirement that the land be free from prior liens. ${ }^{178}$
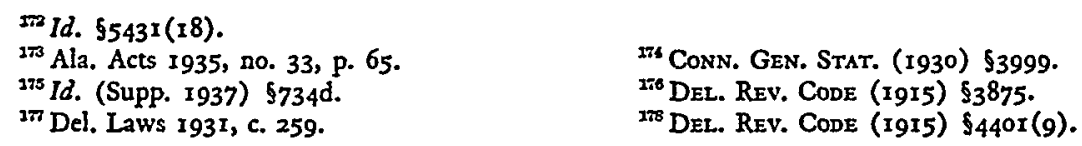
Florida. A 1929 Florida statute sanctioned investment by trustees in first mortgages with a debt limit of $60 \%{ }^{179}$ The legal list adopted in $193^{180}$ changed these provisions and was, in turn, amended in 1937.181 The latter act authorizes investments in first mortgages on improved Florida real estate located within five miles of a city of 2,000. Mortgage investments, which may not exceed $40 \%$ of the principal of the trust, are subject to a debt limit of $60 \%$ of the fair market value of the property as appraised by two qualified persons within the last 30 days. If the mortgage exceeds $50 \%$, it must provide for at least annual principal payments so as to reduce the debt, within three years, to an amount not exceeding $50 \%$. The mortgage must be prior to other liens except taxes assessed but not due. Improvements are to be insured by the mortgagor, with loss payable to the mortgagee. The above limitations do not apply to mortgages insured by the Federal Housing Administrator.

Indiana. Indiana's legal list adopted in 1933 authorizes investments in obligations maturing within five years or providing for an annual principal reduction of at least $5 \%$, secured by first mortgage or improved Indiana real estate owned in fee simple. ${ }^{182}$ The debt limit is restricted to $50 \%$ of the property's value, determined by an appraisal of two competent disinterested persons made within the last year.

Nebraska. Prior to 1930 loans on real estate were limited to $40 \%$ of its appraised value. ${ }^{183}$ A statute enacted in 1935 restricted such loans to first mortgage security on realty in Nebraska. ${ }^{184}$ The act permits renewals where, because of shrinkage in real estate values, the loan has exceeded $40 \%$ of the property's value, and the acceptance of purchase money mortgages up to $40 \%$ on real estate sold. An amendment in 1937 raised the debt limit to $50 \%$ of the appraised value at the time of investment. ${ }^{185}$

New Hampshire. The legislature in $193 \mathrm{I}$ added to the section relating to mortgages on real estate outside New Hampshire the requirement that no loan investment be made upon real estate located other than in New England except through or from an individual or business association registered in New Hampshire as a dealer in securities, and no such loan should be made except upon written application showing the date, name of applicant, amount asked for, and security offered. ${ }^{180}$

New Jersey. In 1933 an act relating only to mortgages extends the powers of trustees concerning mortgage investments. ${ }^{187}$ The trustees are authorized to invest in mortgages on real estate subject to non-delinquent taxes or assessments or to certain specified types of incumbrances such as rights of way, party walls, restrictive covenants, and leases, where no rights of re-entry or forfeiture are reserved. The same act authorizes renewals of mortgages, made in good faith and reasonable discretion, on realty depreciated in value so that the lien exceeds the proportion of value permitted for mortgage investments, or on realty subject to municipal liens.

${ }^{100}$ Fla. Laws 1929, c. 13576, 528.

${ }_{151}$ 1d. 1937 , c. 17949.

${ }^{153}$ Neb. CoMp. Stut. (1929) $\$ 8-206$.

${ }^{250}$ Neb. Laws 1937, c. 60.

${ }^{187}$ N. J. Laws 1933, c. 204.
${ }^{190}$ Id. I93I, c. 15064 .

${ }_{100}$ INd. STAT. (Baldwin, Supp. 1937) \$7908(c).

198 Id. (Supp. 1935) \$27-601.

${ }^{136}$ N. H. Laws I931, c. 96. 
New York. An act passed this year prohibits investment in mortgages on vacant or unimproved real estate. ${ }^{188}$ The amount which may be loaned upon mortgages on residential property has been increased from $60 \%$ to $66 \% \%$ of the appraised value.

Ohio. Trustees in Ohio may invest in securities legal for savings banks in addition to those listed separately for fiduciaries. ${ }^{188}$ The section dealing with the latter was amended in 1933 so as to add first mortgages on real estate held in fee, with a debt limit of $50 \%{ }^{190}$ The provisions for investment by savings banks in ground rents was removed in $1937 .{ }^{101}$

Oregon. Oregon in 193I modified its requirement that mortgage investments be made only on otherwise unencumbered real estate, by permitting the real estate to be subject to taxes and bonded debts for public improvements not yet due, provided the obligation purchased plus such taxes and bonded debt does not exceed 50\% of the reasonable market value of the property. ${ }^{192}$ The law regulating investments by charitable and educational trustees was similarly amended in 1937, except that the taxes might be overdue for not more than three months and the total debt limit of $50 \%$ was increased to $60 \%$ of the actual cash value of the property. ${ }^{193}$

Pennsylvania. Before 1935 trustees were authorized to invest in first mortgages on real estate in Pennsylvania, subject to a debt limit of two-thirds of the fair value of the mortgaged property. ${ }^{194}$ The $1935 \mathrm{act}^{195}$ added the restriction that the property be improved and specified that the lien be prior to all other liens except taxes not yet payable, permitting provision for taxes due or delinquent to be made in the mortgage settlement. The debt limit remains the same. The mortgages are to be payable within five years of their date or renewal, within 20 years thereof or be amortized in instalments totalling each year at least $3 \%$ of the obligations secured. At the date of investment no interest may be due.

The provision for investment in bonds secured by deeds of unencumbered Pennsylvania real estate conveyed to a corporation authorized to act as trustee for bondholders, ${ }^{196}$ was also amended in 1935 to require that the real estate be improved and to exclude real estate used as a theatre or for manufacturing purposes. ${ }^{197}$ The mortgage or trust deed must be a first lien and contain a provision for amortization by annual payments of at least $2 \%$ of the maximum amount of the bonds outstanding at any, time, plus an amount equal to the interest on all bonds previously retired thereby. There must have been no default in interest or amortization payments. For investments made after the original or renewal date of the mortgage, no new appraisal is required if one has been made within three years and a competent reputable person familiar with local real estate values and with the previous appraisal certifies that at the date of the investment the bonds do not exceed two-thirds of fair value. Other requirements remain unchanged.

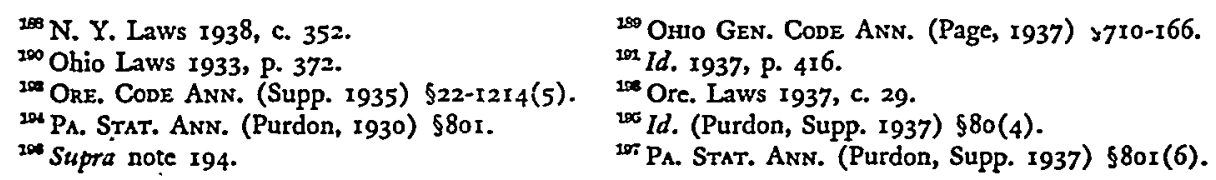


The former authorization to invest "in ground rents in this Commonwealth"108 was qualified in 1935 by the provision that the annual rent reserved in a ground rent, capitalized at $5 \%$, not exceed two-thirds the fair value of the real estate. ${ }^{100}$

Tennessee. The legal list, enacted in $193{ }^{1},{ }^{200}$ authorizes investment in first mortgages on real estate within the state, with a debt limit of $50 \%$ of the actual value as appraised by a licensed real estate dealer, acting for individual trustees, or by an agent or committee composed of, or selected by, the board of directors or executive committee of an incorporated trustee. The trustee is limited to a $1 \%$ commission from the borrower. Upon application of the beneficiary or in order to protect the trust, the court having jurisdiction may prevent the investment in, or order the sale of, such obligations.

Virginia. The legislature in 1934 altered the provisions for investment in mortgages by removing the authorization to invest in obligations collaterally secured. ${ }^{201}$

\section{Special Provisions Relating to Mortgage Participations.}

Eight states since 1929 have enacted legislation relating to participating mortgages. The 1937 Alabama act ${ }^{202}$ prohibits purchase by a trustee of an interest or participation in an obligation secured by a mortgage unless the entire principal debt is controlled by the trustee. The trustee is forbidden to sell any interest less than the entire obligation to any person or trust not controlled by him.

The Florida statute of 1937 provides that the mortgage is to secure no debt other than that owing to the trustee. ${ }^{203}$ A 1937 Michigan statute excludes inyestment in mortgage participations. ${ }^{204}$ Kentucky in 1936 authorized trust companies to set apart in a real estate mortgage fund mortgages conforming to the Kentucky requirements, to issue against such fund participation certificates covering fractional interests, and to invest trust funds in the certificates. ${ }^{205}$

A New Jersey statute passed in $1933^{200}$ provides that trustees, who were authorized by prior laws to invest in participation mortgages, may purchase primary or senior parts of such mortgages if such parts do not exceed that proportion of the estimated worth or appraised value of the property which is applicable to mortgage investments, even though the mortgage secures also secondary or junior part which exceeds that proportion. The trustee may enter into agreements with other holders of interests in a mortgage to make the interest held by the trustee a senior part.

New York in 1936 enacted statutes which amended the Personal Property and Decedents' Estates Laws by removing the authorization for investments in participating mortgages. ${ }^{207} \mathrm{~A}$ few days later another act was approved amending in other respects the same law as it existed before earlier amendments, seemingly reinstating

${ }^{108}$ Supra note 194.

100 P.. Stat. ANn. (Purdon, Supp. 1937) \$801(5). ${ }^{200}$ Tenn. Acts I931, c. Ioo.

${ }^{201}$ VA. CODE (Michie, I936) 3543I(6.7). The amendment applies both to mortgages on land located in Virginia and in citics elsewhere in the United States.

${ }_{200}$ Ala. Acts Spec. Sess. 1936-37, no. 86, p. 79. ${ }_{200}^{203 p r a ~ n o t e ~ 181 . ~}$

${ }^{204}$ Mich. Laws 1937, no. 177, p. 271.

${ }^{200}$ Supra note 187.

\footnotetext{
${ }^{200} \mathrm{Kx}$. STAT. (Carroll, Baldwin's rev., 1936) $\$ 4706$.

${ }^{20 r}$ N. Y. Laws 1936, cc. $264,265$.
} 
participations as legal investments. ${ }^{208}$ Later in the same year trust companies were prohibited from making such investments. ${ }^{200}$ Finally, in 1937 , the laws were again amended so as to remove the authority to invest in participating mortgages. ${ }^{210}$

The Ohio statute of 1933 provides that if the obligations secured by mortgages authorized by that act to be purchased are only parts of the obligations secured thereby, the parts purchased by trustees must belong to the most preferred class and have equal priority with all other obligations of the same class so secured.211

Along with the authorization for common trust funds Pennsylvania in I935 sanctioned investments in fractional interests in mortgages or in a pool or fund containing mortgages. ${ }^{212}$ The provision for certification of the value of the mortgaged property is identical to the Pennsylvania provision as to mortgage bond issues digested in the first part of this section.

A Tennessee statute of $193^{213}$ allows investment in share and participation certificates of investment trusts whose funds are entirely invested at the time and whose trust articles or by-laws require the funds always to be invested in cash or in bonds secured by mortgage or trust deed or real estate within the state. - Participations certificates may be issued by a trustee or any authorized trust institution located in Tennessee.

\section{Miscellaneous Securities}

Investment Trusts. Oregon in $1937^{214}$ passed a statute permitting investment by trustees for charitable and educational purposes, in shares and participation certificates of investments trusts. The authorization is qualified by the restrictions that the trust must have existed eight years, having average earnings applicable to dividends or income distributions equal to at least $4 \%$ per annum upon the purchase price, during the last five years. Not more than $10 \%$ of the funds held in a trust may be invested in such securities, and not more than $5 \%$ in those of any one investment trust.

Annuity Contracts. Florida's revised legal list of 1937 includes annuity or endowment contracts with life insurance companies qualified to do business within the state. $^{215}$ A Massachusetts statute, passed the same year, ${ }^{216}$ permits probate courts, upon application by a trustee, to authorize investments in policies of life or endowment insurance or annuity contracts, on the life of the beneficiary or any person in whose life the beneficiary has an insurable interest. Ohio in $1933^{217}$ added to its legal list life, endowment, or annuity contracts of legal reserve life insurance companies, and Wisconsin in $1935^{218}$ added single premium endowment insurance policies and annuities of authorized insurance companies.

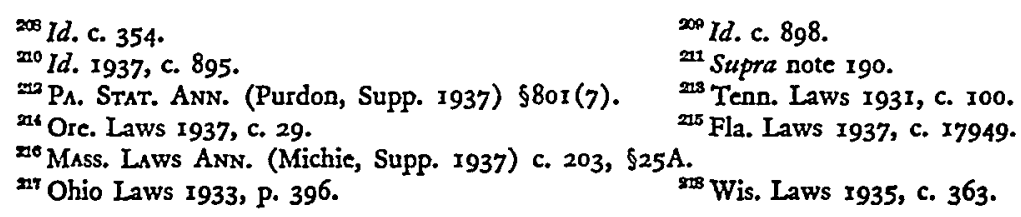


Building and Loan Associations. Iowa, North Carolina, and Oregon ${ }^{210}$ have authorized trustees to purchase shares in building and loan associations incorporated within the respective states. In North Carolina the investment may be made only with the authorization of the insurance commissioner, and in Oregon the trustee may make such purchases only upon approval of the court having jurisdiction.

Securities Omitted. Statutes relating to special types of investments not included in this and foregoing sections were enacted in a few states, but their significance was deemed so slight as to justify their omission from this study.

\section{General Provisions Relating to Investments}

"Prudent Man" Rule. Trustees in Kentucky may invest in "interest-bearing or dividend-paying securities which would be regarded by prudent business men as safe investments." ${ }^{220}$ Before 1932 this rule was qualified by the restriction that no investments were to be made in railroad or other corporate securities unless the obligor had been in existence ten years without default, and investments in municipal obligations were limited to those of obligors with a no-default record of ten years. ${ }^{221}$ These restrictions were removed in that year. ${ }^{222}$

Michigan in 937 enacted a law which provided that, in the absence of specifications in the trust instrument, investments may be made in any securities which an "ordinarily prudent man of intelligence and integrity, who is a trustee of the moneys of others," would purchase, excluding mortgage participations and securities purchased from the trustee or an affiliate or subsidiary. ${ }^{223}$

A statute passed in Utah in $1933^{224}$ provides that when the trust instrument authorizes a trust company, its officers, or directors to exercise discretion in making investments, trust funds may be invested only in those securities approved by the directors of the company or a committee of the directors appointed for that purpose.

Retention of "Originals." Since I930 Florida, Maine, Nebraska, and Pennsylvania $^{225}$ have passed statutes authorizing trustees in the exercise of reasonable judgment to retain securities received by them from the creator of the trust, without liability for loss, though they were not otherwise legal investments when received.

Retention of Ineligible Investments. With the changes in their legal lists, California, Delaware, Florida, New York, Pennsylvania, Virginia, and Wisconsin ${ }^{226}$ have provided that investments legal when made may be retained by trustees in the exercise of reasonable care though they later cease to meet the requirements set out in the lists. A 1937 Indiana statute, however, specifies that unauthorizd investments held or received by a trustee must be sold before July, 1939, or within a year after

Iowa Acts 1933, c. 165; N. C. Code (Michie, 1935) \$4018(b); Ore. Code ANN. (Supp. 1935) 525-373.

${ }_{200}$ KY. StAT. (Carroll, Baldwin's rev., 1936) $\$ 4706$.

$21 d$. (Carroll, Baldwin's rev., 1930) \$4706. 202 Ky. Acts r932, c. 9r.

${ }^{203}$ Mich. Laws 1937, no. 177, p. 271. 24 Utah Laws 1933, c. 10.

$\approx$ Fla. Laws 1937, c. I7949; Me. Laws 1937, c. 145; NEB. Comp. Stat. (Supp. 1935) \$27-601; PA. Srat. AnN. (Purdon, Supp. 1937) 5801(19c).

${ }^{8}$ CAL. STAT. 1937, c. 34I; DEI. Rev. CODE (I935) \$440I(E); Fla., supra note 215; N. Y. LaWs 1938, c. 356; P2., supra note 225; VA. CODE (Michic, 1936) 5543I(c); Wis. Laws 1935, c. 363 . 
their receipt, unless otherwise directed by the beneficiaries, the court having jurisdiction, or the trust instrument. ${ }^{227}$

Securities Obtained Other Than By Purchase. In I93I Delaware added a provision permitting trustees to take over, other than by purchase, any securities not within the legal list and retain them in the exercise of reasonable care, without liability for loss. ${ }^{228}$ A similar authorization has been passed in Florida. ${ }^{229}$ A New York law of $1934^{230}$ sanctions the acquisition by trustees of any securities obtained in settlements or reorganizations effected to secure loans or defaulted securities. This act is to remain in force for a period of five years.

Authorization by Beneficiaries. In $193^{281}$ an act was passed in Indiana permitting investment in any property which the trustee is directed to purchase by the written consent of each beneficiary, where all are competent and the direction is not contrary to the terms of the trust instrument.

Limitation of Investment. An Indiana act of $193 \%$, amending statutes passed in 1933 and 1935 , limits to $\$ 5,000$ or one-tenth in fair cash value, whichever is greater, the amount of the trust estate which may be invested in the obligations of any one debtor. This limitation does not apply to the obligations of Indiana or the United States. ${ }^{232}$

mInd. Laws I937, c. 33.

200 Supra note 215.

Ind. Stat. (Baldwin, Supp. I937) \$7908.
20 Del. Rev. Code (1935) $\$ 4401$ (D).

200 N. Y. BANkING LaW \$239-b.

Id. $\$ 7909$. 